\title{
Application of Organic Manures and their Influence on Broccoli Growth and Yield Parameters
}

\author{
Vishaw Vikas $^{1 *}$, A. K. Mondal ${ }^{1}$, Jag Paul Sharma ${ }^{2}$ and Divyansh Verma ${ }^{1}$ \\ ${ }^{1}$ Division of Soil Science \& Agricultural Chemistry, SKUAST Jammu \\ ${ }^{2}$ Directorate of Research, SKUAST Jammu, India \\ *Corresponding author
}

Keywords

Broccoli Growth and Yield

Parameters, Organic Manures

Article Info

Accepted: 08 January 2020 Available Online: 10 February 2020

\section{A B S T R A C T}

A study was conducted at Organic Farming Research Centre of SKUAST Jammu to find out the impact of organic manures and their influence on Broccoli growth and yield parameters. In this two year experiment, all broccoli growth parameters showed a significant impact on broccoli growth and yield parameters which were size of curd, plant height, curd weight and curd diameter. Maximum and minimum value in size of curd identified was $5.86 \mathrm{~cm}$ and $5.13 \mathrm{~cm}$ in $\mathrm{T}_{8}$ and $\mathrm{T}_{1}$. Maximum and minimum value in plant height identified was $63.83 \mathrm{~cm}$ and $55.20 \mathrm{~cm}$ in $\mathrm{T}_{8}$ and $\mathrm{T}_{1}$.As per tukey's post hoc analysis non-significant effect of treatments was observed on number of leaves as maximum and minimum value identified was 12.66 and 10.33 in $\mathrm{T}_{10}$ and $\mathrm{T}_{1}$.Maximum and minimum value in curd weight identified was $314.33 \mathrm{~g}$ and $275.66 \mathrm{~g}$ in $\mathrm{T}_{8}$ and $\mathrm{T}_{1}$.Maximum and minimum value in curd diameter identified was $11.73 \mathrm{~cm}$ and $10.33 \mathrm{~cm}$ in $\mathrm{T}_{8}$ and $\mathrm{T}_{1}$. The additive effect of organic manures continuously improvised the growth and yield in comparison to time.

\section{Introduction}

Continuous and massive application of fertilizers during early seventies helped in improving the soil fertility and also the replenishment of nutrients lost due to abiotic factors or consumed by the plants and ushered an era of green revolution. After 50 years of green revolution, the continuous trend of application of fertilizers in imbalanced way because of some govt. policies like subsidy on urea led to the emergence of problem of soil and water bodies' pollution by nitrate. As a result, economic efficiency of fertilizers use as well as quality of crop products deteriorated. History is the witness that organic manure based agro-production systems continues to support the agriculture growth both quantitatively as well as qualitatively. Researchers concluded that 
Organic Nutrient Management in agriculture as a way tends to be more promising and reliable to take on all the issues pertaining soil, climate and crop productivity sustainably (Sudha and Chandini 2003). Broccoli (Brassica oleraceaL.var. italica) belongs to family Brassicaceae. It is a fast growing vegetable crop andmostly requires high nitrogen input for proper growth and development. It is highly nutritious with essential vitamins and minerals (Michaud et. al., 2002).

\section{Materials and Methods}

Geographically the experimental site is located at $32^{\circ} 39^{\prime} 35.5^{\prime \prime} \mathrm{N}$ latitude and $74^{\circ} 47^{\prime} 35.0^{\prime \prime E}$ longitude at an elevation of 332 meters above the mean sea level in site the Shivalik foothill plains of North-Western Himalayas.

Surface soil sampling from $0-15 \mathrm{~cm}$ depth was done randomly from four spots of the field prior to start of experiment. The soil samples collection were mixed together to form respective composite sample.

\section{Experimental details}

The experiment consisted of 10 treatments given in Table A.

*Blanket application of FYM @ 10 tonneha $^{-1}$ was done

**Dhaincha was incorporated as a source of green manure

\section{Crop and site detail}

Total treatments :- 10

Total replications:- 3

Total no. of plots:- 30

Design: RCBD

\section{Okra}

Spacing:- 45cms (Row) X 30cms (Plant)

Variety:- Seli Special

Seed rate:- $20-25 \mathrm{~kg} \mathrm{ha}^{-1}$

$\mathrm{N}: \mathrm{P}: \mathrm{K}$ requirement:- 100:60:60

\section{Broccoli}

Spacing:- 60cms (Row) X 45cms (Plant)

Variety:- Early Green

Seed rate:- 300-400 $\mathrm{g} \mathrm{ha}^{-1}$

$\mathrm{N}: \mathrm{P}: \mathrm{K}$ requirement:- 120:60:60

\section{Dhaincha}

Dhaincha seed was broadcasted in the experimental field @ $50 \mathrm{~kg} \mathrm{ha}^{-1}$ and green matter was incorporated 45 DAS.

\section{Experimental site}

Organic Farming Research Centre of SKUAST -Jammu

Vegetative growth characteristics were measured on a random sample of ten plants, taken from each experimental bed and the data was recorded.

All broccoli heads of each plot were harvested at marketable stage.

\section{Statistical analysis}

The data on various characters studied during the course of investigation were statistically analyzed by using Tukey's test with an aim to figure out which groups in our sample differ by using "Honest Significant Difference," a number that represents the distance between groups, to compare every mean with every other mean. 
Table.A Treatment details

\begin{tabular}{|c|c|c|}
\hline Treatments & Input & $\begin{array}{c}\text { Qty. applied tonne ha-1 on the } \\
\text { basis of Nitrogen requirement } \\
* * *\end{array}$ \\
\hline $\mathbf{T}_{\mathbf{1}}$ & No application & Nil \\
\hline $\mathbf{T}_{\mathbf{2}}$ & Farm Yard Manure & 10.00 \\
\hline $\mathbf{T}_{\mathbf{3}}$ & Vermicompost & 6.60 \\
\hline $\mathbf{T}_{\mathbf{4}}$ & Poultry Manure & 2.91 \\
\hline $\mathbf{T}_{\mathbf{5}}$ & Neem Cake & 2.00 \\
\hline $\mathbf{T}_{\mathbf{6}}$ & Farm Yard Manure + Poultry Manure & $5+1.45$ \\
\hline $\mathbf{T}_{\mathbf{7}}$ & Farm Yard Manure + Neem Cake & $5+1.00$ \\
\hline $\mathbf{T}_{\mathbf{8}}$ & Vermicompost + Poultry Manure & $3.30+1.45$ \\
\hline $\mathbf{T}_{\mathbf{9}}$ & Vermicompost + Neem Cake & $3.30+1.00$ \\
\hline $\mathbf{T}_{\mathbf{1 0}}$ & Neem Cake + Poultry Manure & $1.00+1.45$ \\
\hline & & \\
\hline
\end{tabular}

\section{Results and Discussion}

\section{Size of curd in broccoli}

During $1^{\text {st }}$ year of experiment, significant improvement in size of curd was observed in broccoli as compared to control (Table 1). In year 2016, the maximum value observed was $5.53 \mathrm{~cm}$ in $\mathrm{T}_{8}$ and minimum observed was $4.93 \mathrm{~cm}$ in $\mathrm{T}_{1}$. Also in individual applications the $\mathrm{T}_{4}$ performance with value $5.33 \mathrm{~cm}$ was better and was found at par with $\mathrm{T}_{7}, \mathrm{~T}_{9}$ and $\mathrm{T}_{10}$. In combination of manures, the best performing treatment was $T_{8}$ in which the highest value $5.53 \mathrm{~cm}$ was noticed. Also, $\mathrm{T}_{5}$ was found at par with $T_{2}$ and $T_{3}$.

In consecutive year 2017, again significant effect of treatments was observed. Maximum and minimum value identified was $5.86 \mathrm{~cm}$ and $5.13 \mathrm{~cm}$ in $\mathrm{T}_{8}$ and $\mathrm{T}_{1}$. In individual treatment, the $\mathrm{T}_{4}$ performed well as highest value notified was $5.60 \mathrm{~cm}$ and was found at par with $\mathrm{T}_{7}$ and $\mathrm{T}_{9}$. In combination context, the finest performance was observed in $\mathrm{T}_{8}$ which depicted highest value of $5.86 \mathrm{~cm}$. Also, $\mathrm{T}_{5}$ was found at par with $T_{2}$ and $T_{3}$. Similarly, $\mathrm{T}_{10}$ was found at par with $\mathrm{T}_{6}$.

Similarly, in mean values the maximum value 5.73 cmwas observed in $T_{8}$ and minimum was $5.03 \mathrm{~cm}$ in $\mathrm{T}_{1}$. Also, $\mathrm{T}_{5}$ was found at par with $\mathrm{T}_{3}$.

\section{Plant height of broccoli}

During $1^{\text {st }}$ year of experiment, significant improvement in plant height was observed in broccoli as compared to control (Table 2). In year 2016, the maximum value observed was $57.36 \mathrm{~cm}$ in $\mathrm{T}_{8}$ and minimum observed was $51.96 \mathrm{~cm}$ in $\mathrm{T}_{1}$. Also in individual applications the $\mathrm{T}_{4}$ performance with value $55.13 \mathrm{~cm}$ was better. In combination of manures, the best performing treatment was $\mathrm{T}_{8}$ in which the highest value $57.36 \mathrm{cmwas}$ noticed and was found at par with $\mathrm{T}_{6}$ and $\mathrm{T}_{10}$. In consecutive year 2017, again significant effect of treatments was observed. Maximum and minimum value identified was $63.83 \mathrm{~cm}$ and $55.20 \mathrm{~cm}$ in $\mathrm{T}_{8}$ and $\mathrm{T}_{1}$. In individual treatment, the $\mathrm{T}_{4}$ performed well as highest 
value notified was $60.53 \mathrm{~cm}$ and was found at par with $\mathrm{T}_{10}$. In combination context, the finest performance was observed in $\mathrm{T}_{8}$ which depicted highest value of $63.83 \mathrm{~cm}$. Also, $\mathrm{T}_{5}$ was found at par with $T_{3}$.

Similarly in mean values the maximum value 60.63 cmwas observed in $\mathrm{T}_{8}$ and minimum was $53.63 \mathrm{~cm}$ in $\mathrm{T}_{1}$. Also, $\mathrm{T}_{5}$ was found at par with $\mathrm{T}_{3}$.

\section{Number of leaves of broccoli}

During $1^{\text {st }}$ year of experiment, no significant improvement in leaf number was observed in broccoli as compared to control (Table 3). In year 2016, the maximum value observed was 12.00 in $\mathrm{T}_{8}$ and minimum observed was 10.00 in $T_{1}$. Also in individual applications the $T_{3}$ performance with value 11.33 was better. In combination of manures, the best performing treatment was $T_{8}$ in which the highest value 12.00was noticed.

In consecutive year 2017, again as per tukey's post hoc analysis non-significant effect of treatments was observed.

Maximum and minimum value identified was 12.66 and 10.33 in $T_{10}$ and $T_{1}$. In individual treatment, the $T_{3}$ and $T_{4}$ performed at par as value notified was 12.00. In combination context, the finest performance was observed in $\mathrm{T}_{10}$ which depicted highest value of 12.00 .

Similarly, in mean values the maximum value 12.16was observed in $\mathrm{T}_{10}$ and minimum was 10.16 in $\mathrm{T}_{1}$.

\section{Curd weight}

During $1^{\text {st }}$ year of experiment, significant improvement in curd weight was observed in broccoli as compared to control (Table 4). In year 2016, the maximum value observed was $301.66 \mathrm{~g}$ in $\mathrm{T}_{8}$ and minimum observed was $269.33 \mathrm{~g}$ in $\mathrm{T}_{1}$. Also in individual applications the $\mathrm{T}_{4}$ performance with value $289.66 \mathrm{~g}$ was better and was at par with $T_{9}$. In combination of manures, the best performing treatment was $T_{8}$ in which the highest value 301.66 gwas noticed. $T_{5}$ was found at par with $\mathrm{T}_{3}$ and $T_{2}$. Also $T_{10}$ was found at par with $T_{6}$.

In consecutive year 2017, again significant effect of treatments was observed. Maximum and minimum value identified was $314.33 \mathrm{~g}$ and $275.66 \mathrm{~g}$ in $\mathrm{T}_{8}$ and $\mathrm{T}_{1}$. In individual treatment, the $\mathrm{T}_{4}$ performed well as highest value notified was $300.33 \mathrm{~g}$. In combination context, the finest performance was observed in $T_{8}$ which depicted highest value of 314.33 g. Also, $T_{9}$ was found at par with $\mathrm{T}_{7}, \mathrm{~T}_{5}$ and $\mathrm{T}_{3}$. Similarly, $\mathrm{T}_{10}$ was found at par with $\mathrm{T}_{6}$ and $T_{3}$ was found at par with $T_{2}$.

In mean values the maximum value 308.00 gwas observed in $\mathrm{T}_{8}$ and minimum was $272.50 \mathrm{~g}$ in $\mathrm{T}_{1}$. Also, $\mathrm{T}_{5}$ was found at par with $\mathrm{T}_{2}$ along with $\mathrm{T}_{7}$ was found at par with $\mathrm{T}_{9}$.

\section{Curd diameter}

During $1^{\text {st }}$ year of experiment, significant improvement in curd diameter was observed in broccoli as compared to control (Table 5). In year 2016, the maximum value observed was $11.10 \mathrm{~cm}$ in $\mathrm{T}_{8}$ and minimum observed was $9.90 \mathrm{~cm}$ in $\mathrm{T}_{1}$. Also in individual applications the $\mathrm{T}_{4}$ performance with value $10.63 \mathrm{~cm}$ was better. In combination of manures, the best performing treatment was $\mathrm{T}_{8}$ in which the highest value $11.10 \mathrm{cmwas}$ noticed. $T_{5}$ was at par $T_{3}$ and $T_{9}$ was found at par with $\mathrm{T}_{7}$. Also, $\mathrm{T}_{10}$ was found at par with $\mathrm{T}_{6}$.

In consecutive year 2017, again significant effect of treatments was observed. Maximum and minimum value identified was $11.73 \mathrm{~cm}$ and $10.33 \mathrm{~cm}$ in $\mathrm{T}_{8}$ and $\mathrm{T}_{1}$. In individual treatment, the $\mathrm{T}_{4}$ performed well as highest value notified was $11.20 \mathrm{~cm}$. In combination context, the finest performance was observed 
in $\mathrm{T}_{8}$ which depicted highest value of 11.73 $\mathrm{cm}$. Also, $\mathrm{T}_{9}$ was found at par with $\mathrm{T}_{7}, \mathrm{~T}_{5}, \mathrm{~T}_{3}$ and $\mathrm{T}_{2}$. Similarly, $\mathrm{T}_{10}$ was found at par with $\mathrm{T}_{6}$.

Similarly, in mean values the maximum value 11.43 cmwas observed in $\mathrm{T}_{8}$ and minimum was $10.10 \mathrm{~cm}$ in $\mathrm{T}_{1}$. Also, $\mathrm{T}_{5}$ was found at par with $T_{2}$ and $T_{3}$. $T_{9}$ was found at par with $T_{7}$ and $\mathrm{T}_{4}$. Also, $\mathrm{T}_{10}$ was found at par with $\mathrm{T}_{6}$.

\section{Effect on manures on soil quality}

The ultimate purpose of researching and assessing soil quality is not to achieve high aggregate stability, biological activity, or some other soil property. It's basically is to protect and improve long-term agriculture productivity, water quality, and habitats of all organisms, including people. We use soil characteristics as indicators of soil quality, but in the end, soil quality must be identified by how soil performs its functions.This short duration experiment conducted in year 2016 and 2017 in which maximum soil parameters like $\mathrm{pH}, \mathrm{EC}, \mathrm{OC}$, Available potassium, sulphur, Total N, Zn, Mn, $\mathrm{Cu}, \mathrm{Ca}, \mathrm{Mg}$, Microbial Biomass Nitrogen and Acid Phosphatase values were found to be nonsignificant as minor variations in treatments were observed as compared to control but still due to the additive effects of organic manures the all parameters trend was continuously observed improvised in comparison to time except Potassium. In an overall reflectance of soil parameters impact on soil health there seems a very less improvement due to the short span of experiment i.e. 2 years, however major improvements in all soil quality parameter might be expected in further course of time.

Table.1 Effect of organic manures on size of curd $(\mathrm{cm})$ in broccoli

\begin{tabular}{|l|c|c|c|}
\hline \multicolumn{1}{|c|}{ Treatment } & $\mathbf{2 0 1 6}$ & $\mathbf{2 0 1 7}$ & Mean \\
\hline T1: Control & $4.93^{\mathrm{a}}$ & $5.13^{\mathrm{a}}$ & $5.03^{\mathrm{a}}$ \\
\hline T2: FYM & $5.20^{\mathrm{b}}$ & $5.43^{\mathrm{b}}$ & $5.30^{\mathrm{b}}$ \\
\hline T3: VC & $5.20^{\mathrm{b}}$ & $5.50^{\mathrm{b}}$ & $5.33^{\mathrm{bc}}$ \\
\hline T4: PM & $5.33^{\mathrm{bc}}$ & $5.60^{\mathrm{bc}}$ & $5.46^{\mathrm{cde}}$ \\
\hline T5: NC & $5.20^{\mathrm{b}}$ & $5.43^{\mathrm{b}}$ & $5.33^{\mathrm{bc}}$ \\
\hline T6: FYM + PM & $5.40^{\mathrm{c}}$ & $5.73^{\mathrm{cd}}$ & $5.56^{\mathrm{e}}$ \\
\hline T7: FYM + NC & $5.26^{\mathrm{bc}}$ & $5.53^{\mathrm{bc}}$ & $5.43^{\mathrm{bcde}}$ \\
\hline T8: VC + PM & $5.53^{\mathrm{d}}$ & $5.86^{\mathrm{d}}$ & $5.73^{\mathrm{f}}$ \\
\hline T9: VC + NC & $5.26^{\mathrm{bc}}$ & $5.53^{\mathrm{bc}}$ & $5.40^{\mathrm{bcd}}$ \\
\hline T10: $\mathbf{N C}+$ PM & $5.33^{\mathrm{bc}}$ & $5.73^{\mathrm{cd}}$ & $5.53^{\mathrm{de}}$ \\
\hline
\end{tabular}

* Mean values with similar alphabet in a subset are statistically at par. 
Table.2 Effect of organic manures on plant height $(\mathrm{cm})$ of broccoli

\begin{tabular}{|l|c|c|c|}
\hline \multicolumn{1}{|c|}{ Treatment } & $\mathbf{2 0 1 6}$ & $\mathbf{2 0 1 7}$ & Mean \\
\hline T1: Control & $51.96^{\mathrm{a}}$ & $55.20^{\mathrm{a}}$ & $53.63^{\mathrm{a}}$ \\
\hline T2: FYM & $53.03^{\mathrm{b}}$ & $57.50^{\mathrm{b}}$ & $55.30^{\mathrm{b}}$ \\
\hline T3: VC & $54.66^{\mathrm{c}}$ & $59.00^{\mathrm{c}}$ & $56.76^{\mathrm{c}}$ \\
\hline T4: PM & $55.13^{\mathrm{cde}}$ & $60.53^{\mathrm{de}}$ & $57.86^{\mathrm{de}}$ \\
\hline T5: NC & $54.70^{\mathrm{cd}}$ & $59.00^{\mathrm{c}}$ & $56.90^{\mathrm{c}}$ \\
\hline T6: FYM + PM & $56.76^{\mathrm{f}}$ & $61.86^{\mathrm{f}}$ & $59.33^{\mathrm{g}}$ \\
\hline T7: FYM + NC & $55.70^{\mathrm{e}}$ & $61.33^{\mathrm{ef}}$ & $58.50^{\mathrm{ef}}$ \\
\hline T8: VC + PM & $57.36^{\mathrm{f}}$ & $63.83^{\mathrm{g}}$ & $60.63^{\mathrm{h}}$ \\
\hline T9: VC + NC & $55.40^{\mathrm{de}}$ & $59.80^{\mathrm{cd}}$ & $57.60^{\mathrm{d}}$ \\
\hline T10: $\mathbf{N C}+\mathbf{P M}$ & $57.00^{\mathrm{f}}$ & $60.53^{\mathrm{de}}$ & $58.76^{\mathrm{fg}}$ \\
\hline
\end{tabular}

*Mean values with similar alphabet in a subset are statistically at par.

Table.3 Effect of organic manures on number of leaves in broccoli

\begin{tabular}{|l|l|l|l|}
\hline \multicolumn{1}{|c|}{ Treatment } & $\mathbf{2 0 1 6}$ & $\mathbf{2 0 1 7}$ & Mean \\
\hline T1: Control & 10.00 & 10.33 & 10.16 \\
\hline T2: FYM & 11.00 & 11.33 & 11.16 \\
\hline T3: VC & 11.33 & 12.00 & 11.66 \\
\hline T4: PM & 11.32 & 12.00 & 11.67 \\
\hline T5: NC & 10.33 & 11.00 & 10.66 \\
\hline T6: FYM + PM & 11.22 & 11.33 & 11.33 \\
\hline T7: FYM + NC & 11.33 & 11.66 & 11.50 \\
\hline T8: VC + PM & 12.00 & 12.00 & 12.00 \\
\hline T9: VC + NC & 10.66 & 11.33 & 11.00 \\
\hline T10: NC + PM & 11.66 & 12.66 & 12.16 \\
\hline
\end{tabular}

*As per Tukey's Post-hoc analysis, the values are non-significant. 
Table.4 Effect of organic manures on curd weight $(\mathrm{g})$ in broccoli

\begin{tabular}{|l|c|c|c|}
\hline \multicolumn{1}{|c|}{ Treatment } & $\mathbf{2 0 1 6}$ & $\mathbf{2 0 1 7}$ & Mean \\
\hline T1: Control & $269.33^{\mathrm{a}}$ & $275.66^{\mathrm{a}}$ & $272.50^{\mathrm{a}}$ \\
\hline T2: $\mathbf{F Y M}$ & $282.33^{\mathrm{b}}$ & $292.66^{\mathrm{b}}$ & $287.50^{\mathrm{b}}$ \\
\hline T3: VC & $282.33^{\mathrm{b}}$ & $294.00^{\mathrm{b}}$ & $288.16^{\mathrm{bc}}$ \\
\hline T4: PM & $289.66^{\mathrm{bc}}$ & $300.33^{\mathrm{bc}}$ & $295.00^{\mathrm{cde}}$ \\
\hline T5: NC & $283.66^{\mathrm{b}}$ & $293.00^{\mathrm{b}}$ & $288.33^{\mathrm{bc}}$ \\
\hline T6: $\mathbf{F Y M}+\mathbf{P M}$ & $294.00^{\mathrm{c}}$ & $306.66^{\mathrm{c}}$ & $300.33^{\mathrm{e}}$ \\
\hline T7: $\mathbf{F Y M}+\mathbf{N C}$ & $288.00^{\mathrm{bc}}$ & $296.33^{\mathrm{b}}$ & $292.16^{\mathrm{bcd}}$ \\
\hline T8: $\mathbf{V C}+\mathbf{P M}$ & $301.66^{\mathrm{d}}$ & $314.33^{\mathrm{d}}$ & $308.00^{\mathrm{f}}$ \\
\hline T9: $\mathbf{V C}+\mathbf{N C}$ & $288.00^{\mathrm{bc}}$ & $296.66^{\mathrm{b}}$ & $292.33^{\mathrm{bcd}}$ \\
\hline T10: $\mathbf{N C}+\mathbf{P M}$ & $291.33^{\mathrm{c}}$ & $306.66^{\mathrm{c}}$ & $299.00^{\mathrm{de}}$ \\
\hline
\end{tabular}

*Mean values with similar alphabet in a subset are statistically at par.

Table.5 Effect of organic manures on curd diameter $(\mathrm{cm})$ in broccoli

\begin{tabular}{|l|c|c|c|}
\hline \multicolumn{1}{|c|}{ Treatment } & $\mathbf{2 0 1 6}$ & $\mathbf{2 0 1 7}$ & Mean \\
\hline T1: Control & $9.90^{\mathrm{a}}$ & $10.33^{\mathrm{a}}$ & $10.10^{\mathrm{a}}$ \\
\hline T2: $\mathbf{F Y M}$ & $10.33^{\mathrm{b}}$ & $10.93^{\mathrm{b}}$ & $10.66^{\mathrm{b}}$ \\
\hline T3: $\mathbf{V C}$ & $10.36^{\mathrm{bc}}$ & $10.96^{\mathrm{b}}$ & $10.70^{\mathrm{b}}$ \\
\hline T4: $\mathbf{P M}$ & $10.63^{\mathrm{cd}}$ & $11.20^{\mathrm{bc}}$ & $10.93^{\mathrm{bc}}$ \\
\hline T5: $\mathbf{N C}$ & $10.40^{\mathrm{bc}}$ & $10.96^{\mathrm{b}}$ & $10.70^{\mathrm{b}}$ \\
\hline T6: $\mathbf{F Y M}+\mathbf{P M}$ & $10.76^{\mathrm{d}}$ & $11.46^{\mathrm{cd}}$ & $11.10^{\mathrm{c}}$ \\
\hline T7: $\mathbf{F Y M}+\mathbf{N C}$ & $10.56^{\mathrm{bcd}}$ & $11.10^{\mathrm{b}}$ & $10.83^{\mathrm{bc}}$ \\
\hline T8: $\mathbf{V C}+\mathbf{P M}$ & $11.10^{\mathrm{e}}$ & $11.73^{\mathrm{d}}$ & $11.43^{\mathrm{d}}$ \\
\hline T9: $\mathbf{V C}+\mathbf{N C}$ & $10.56^{\mathrm{bcd}}$ & $11.10^{\mathrm{b}}$ & $10.83^{\mathrm{bc}}$ \\
\hline T10: $\mathbf{N C}+\mathbf{P M}$ & $10.70^{\mathrm{d}}$ & $11.46^{\mathrm{cd}}$ & $11.06^{\mathrm{c}}$ \\
\hline
\end{tabular}

*Mean values with similar alphabet in a subset are statistically at par.

\section{Broccoli growth parameters}

The increase in size of curd, plant height and curd diameter from application of the poultry manureover control may be attributed to the presence of readilyavailable form of nutrient i.e. ammonia and nitrate (Gross et al., 2008) and also to its property to enhance soil aggregation, soil aeration and water holding capacity, offers good environmental conditions for the root system of broccoli plants. This better availability of soil nutrients and favorablesoil condition resulted in healthy plants with large vegetative growth, which 
lead to higher curd weight and curd diameter as compared to control. Improvement in overall growth attributes of broccoli as compared to control with the application of poultry manure, vermicompost, FYM and combinations might be due to better photosynthesis, energy storage, cell division and cell enlargement, moisture holding capacity, supply of micronutrients and availability of major nutrients due to favorable soil condition (Uddin et al., 2009). Poultry manure also enhanced the vegetative growth of broccoli. It might be due to the fact that poultry manure contains uric acid having 60 per cent nitrogen. The uric acid rapidly changes to ammonia form causing its immediate and efficient utilization for better plant growth and development. These results are in partial conformity with the findings of (Choudhary et al., 2012; Kumar et al., 2013; Mohapatra et al., 2013; Yadav et al., 2016). Similar observations due to incorporation of organic manures with respect to quality attributes were reported by Chaterjee et al., (2005) and Damir and Polat (2011) in broccoli.

\section{Soil quality}

No major variations were observed in the soil properties within a span of two years of organic farming. As such changes in soil quality were not expected during this short period among the various treatments. It has been observed that shorter periods of cultivation do not have significant effect on soil quality as reported in the literature (Lazcano et al., 2013). However, over long periods the continuous uses of manures have had a significant effect on soil quality (Memoli et al., 2017). Van-Camp et al., (2004) found that organic amendments influence soil characteristics by the interdependent modification of biological, chemical and physical properties. Also, quality improvement through an effective management of these properties has the capability of optimizing crop production. The Woburn Market Garden Experiment showed increase in percent $\mathrm{C}$ from $0.87 \%$ to $1.46 \%$ from FYM additions and $2 \%$ from composted FYM additions over a 25 year period (Johnston et al., 1989). Vitosh et al., (1973) calculated that applying fresh cattle manure at 67.2 Mg ha-1 yr-1 increased the organic matter content of a sandy loam soils by $0.1 \%$ each year in 15 year experiment. There are reports in the literature of composts both increasing and lowering the $\mathrm{pH}$ of soils, and others where no or little effect was measured (Crecchio et al., 2001). In relation to soil physical properties effects of organic matter additions vary with climate, soil type, texture and rate and type of organic matter addition. The latter is in agreement with the findings of that quality is more important than quantity in relation to effects of organic matter on aggregate stability. It has also been observed that a greater quantity of organic material is needed to improve soil structural properties than is necessary to supply the nutrient requirements of a growing crop (Tisdall and Oades, 1980) with time. Since, the experiment was of 2 years only, no drastic change has been noticed in all parameters, and however it is possible that after a certain period of time change can be noticed in almost all soil parameters.

It is concluded in the experiment, applications of organic manures have a significant impact on the size of curd, plant height, curd weight and curd diameter. However, no. of leaves on broccoli was found to be non-significant in two year cropping system. The best performing treatment was Treatment No. 8 which includes the application of combination of Vermicompost and Poultry Manure as compared to control. In overall aspect, the application of manures and their combination can have a deep impact on growth and yield of broccoli. 


\section{References}

Chaterjee, B., Ghanti, P., Thapa, U. and Tripathy, P. 2005. Effect of organic nutrition in sprouting broccoli (Brassica oleracea L var. italic Plenck).Veg. Sci.32: 51-54.

Choudhary, S., Soni, A.K. and Jat, N.K. 2012. Effect of organic and inorganic sources of nutrients on growth, yield and quality of sprouting broccoli cv CBH-1. Indian J. Hort. 69: 550-54.

Crecchio, C., Curci, M., Mininni, R., Riccuti, P. and Ruggiero, P. 2001. Short-term effects of municipal solid waste compost amendments on soil carbon and nitrogen content, some enzyme activities and genetic diversity. Biology and Fertility of Soils, 34: 311-318.

Damir, H. and Polat, E. 2011. Effects of broccoli-crispy salad intercropping on yield and quality under greenhouse conditions. African J. Agric. Res.6: 4116-21.

Gross, A., Arusi, R. and Nejidat, A. 2008. Assessment of extraction methods with fowl manure for the production of liquid organic fertilizers. Bioresource Technology, 99: 327-334.

Johnston, A.E., McGrath, S.P., Poulton, P.R. and Lane, P.W. 1989. Accumulation and loss of nitrogen from manure, sludge and compost: long-term experiments at Rothamsted and Woburn. In: J.A. Hansen and K. Henriksen (eds.) Nitrogen in organic wastes applied to soils. Academic Press, London, UK, pp 126-137.

Kumar, M., Das, B., Prasad, K.K. and Kumar, P. 2013. Effect of integrated nutrient management on growth and yield of broccoli (Brassica oleracea var. italica) under Jharkhand conditions, Veg. Sci.40: 117-20.

Lazcano C., Brandon M.G., Revilla P. and
Dominguez D. 2013. Short term effects of organic and inorganic fertilizers on soil microbial community structure and function. Biology and Fertility of Soils, 49(6): 723-733

Memoli V., Marco A., Baldantoni D., Nicola F. and Maisto G. 2017. Short- and longterm effects of a single application of two organic amendments. Ecosphere, 8(11): 1-12

Michaud, D.S., Pietinen, P., Taylor, P.R., Virtanen, M., Virtamo, J. and Albanes, D. 2002. Intakes of fruits and vegetables, carotenoids and vitamins $A$, $\mathrm{E}, \mathrm{C}$ in relation to the risk of bladder cancer inthe ATBC cohort study. British Journal of Cancer, 87: 960-965.

Mohapatra, S.K., Munsi, P.S. and Mahapatra, P.N. 2013. Effect of integrated nutrient management on growth, yield and economics of broccoli (Brassica oleracea L. varitalica Plenck).Veg. Sci., 40: 69-72.

Sudha, B., and Chandini, S. 2003. Vermicompost - potential organic manure for rice. Intensive Agriculture

Tisdall, J.M. and Oades, J.M. 1980.The effect of crop rotation on aggregation in a redbrown earth. Australian Journal of Soil Research, 18: 423-434.

Uddin, J., Solaiman, A.H.M. and Hasanuzzaman, M. 2009. Plant characters and yield of kohlrabi (Brassica oleraceae var. gongyloides) as affected by different organic manures. J. Hort. Sci. Orn. Plants, 1: 0104.

Van-Camp L., Bujarrabal B., Gentile A.-R., Jones R.J.A., Montanarella L., Olazabal C., Selvaradjou S.-K. 2004. Reports of the Technical Working Groups Established under the Thematic Strategy for Soil Protection, EUR 21319 EN/3, 872 p., Office for Official Publications of the European Communities, Luxembourg. 
Vitosh, M.L., Davids, J.F. and Knezek, B.D. 1973. Long-term effects of manure, fertilizer, and plow depth on chemical properties of soil and nutrient movement in a monoculture corn system. Journal of Environmental Quality, 2: 296-299.
Yadav, L.P., Singh, A. and Kumar, S. 2016. Effect of intercropping geometry inorganic-based cropping models of broccoli (Brassica oleracea var. italica).Curr. Hort. 4: 3-9.

\section{How to cite this article:}

Vishaw Vikas, A. K. Mondal, Jag Paul Sharma and Divyansh Verma. 2020. Application of Organic Manures and their Influence on Broccoli Growth and Yield Parameters. Int.J.Curr.Microbiol.App.Sci. 9(02): 1127-1136. doi: https://doi.org/10.20546/ijcmas.2020.902.132 